\title{
Implementing Peace Education In Secondary Schools Of Odisha: Perception Of Stake Holders
}

\author{
Lokanath MISHRA*
}

\begin{abstract}
Peace education is fundamentally a process for engaging people in developing awareness of the causes of conflicts and ways to resolve these in daily life. Education is one of the essential factors that will aid in stopping violence and establishing soc emerged as the consequence of various approaches regarding peace from an educational perspective, is a component of teaching tolerance, sharing and honesty to adults and children. The main purpose of peace education is to encourage students to develop different strategies that would provide social justice, not only in their countries, but also around the world. This paper highlights about the perception of parents and teachers about the concept of peace education and how to implement the peace Education in secondary school
\end{abstract}

Keywords: Peace Education, Conflict, Violence and Curriculum for Secondary School

* Dr., Vivek College of Education-India, munumishra7@gmail.com 


\section{INTRODUCTION AND OVERVIEW OF THE STUDY}

Peace education, as education in general, is socially directed and has its roots in some social intent. Peace education is aimed at teaching individuals the information, attitudes, values, and behavioral competencies needed to resolve conflicts without violence and to build and maintain mutually beneficial, harmonious relationships. There are many approaches to peace education, many of which are based on ideology, practical experience, and good intentions It is absolutely necessary to remain conscious of the social purposes we want peace education to serve, the central problematic being violence in its different forms. Beginning from the value-base of peace, human rights, and democracy, we need to identify the social problems we wish to address and then determine the relevant educational goals. In other words, who is to learn what for the society to overcome the problems identified?

Peace education has been defined as a process of promoting the knowledge, skills, attitudes and values needed to bring about behaviour changes that will enable children, youths and adults to prevent conflict and violence, both overt and structural; to resolve conflict peacefully; and to create the conditions conducive to peace, whether at an intrapersonal, interpersonal, intergroup, national or international level. Peace Educators hope to create in the human consciousness a commitment to the ways of peace. Just as a doctor learns in medical school how to minister to the sick, students in peace education learn how to solve problems caused by violence. Peace education tries to inoculate students against the evil effects of violence by teaching skills to manage conflicts non-violently and by creating a desire to seek peaceful resolutions of conflict. Peace education pedagogy is interactive, with the use of dialogue, deliberation and critical learning. Formal and informal collaboration with other groups and cultures in the community is encouraged. Peace education curricula offer diverse content, form, structure, skills and attitudes that address the needs of alternative perspectives

Ian Harris (1988), another prominent peace educator of our time, outlines the goals of peace education as follows: Students will: 1 . Recognize peace is more than the absence of war and gain a broader understanding of peace as respect for life of all living organisms. 2 . Recognize their fears. 3. Be aware of the amount of economic investment allocated on weapons. 4. Be aware of the presences of inequality among societies and their underlying reasons and gain new perspectives on violence and war based on this new awareness. 5. Learn to resolve conflict constructively. 6. Envision how a new societal structure can be realized within the framework of peace. 7. Learn how to deal constructively with anger, and learn different ways to be peaceful under emotionally challenging times. 8. Understand the concepts of human rights, equality, social justice and non-violent ways to resolve conflicts. 9. Gain self-respect and acceptance and develop skills of critical thinking, communication, empathy and ethics. 10. Develop awareness of the presence of violence in various environments and its impact, as well as of alternative ways to violent behavior. To sum up, peace education, in essence, is building in learners the skills and capacities that enable them to effect positive social change in their communities and the world.

Peace education has recently gained attention all around the world (Yilmaz, 2003). This is because of the increasing recourse to the use of violence in responding to conflict or disagreement between individuals, groups, communi- 
ties and countries. The concept of peace education has attracted numerous definitions and has been seen from different point of view. For example, Gumut (2006) perceives peace education as the deliberate attempt to educate children, youths and adults in the dynamics of conflict prevention and promotion of peace making skills in homes, schools, and communities throughout the world, using all the channels and instruments of socialization. To Fisk (2000), peace education is described as a process wherein people learn ideologies, values, attitudes, more standards, sensitivities to others and new perceptions such that they are moved to take different actions from which they did in the past. On the other hand, Oshita (2006) believes that the aim of peace education becomes not just educating for peace but educating for a "peace capacity". Peace education is essentially a peace empowerment strategy which mainly equips individuals with the knowledge and skills to prevent and manage conflict at intra/inter-personal or intra/inter-group levels.Thus Salomon (2002) has pointed out the main activities of peace ed changing mindsets; As a matter of cultivating a set of rights (particularly in the Third Worldsm, Countries); and disarmament, and the promotion of a culture of peace. Fundamentally, peace education aims at building the peace capacity of people so that they do not only learn to resolve their conflicts through peaceful dialogue but to also live in peace. Similarly, peace education is a behavioural and attitudinal change mechanism which aims at: pre-empting conflict (build-up); preventing conflict outbreaks; resolving conflict and promoting a culture of peace. Basically, peace education aims at systematically inculcating the culture of peace in the minds of individuals with a view to deconstructing the culture of violence from their minds by equipping them with the knowledge, skills and abilities, which would assist individuals to interact peacefully and to collaborate to achieve collective as well as personal goals.

\subsection{Peace Education and Pedagogy at the School}

Baldo and Fumiss (1998) argue that peace education is most effective when the skills of peace and conflict resolution are learned actively and are modeled by the school environment in which pupils are taught. Of course, teachers (and school administrators) are the crucial actors for taking the responsibility of achieving these values. Teachers must be able to foster positive social interactions among children, and establish and maintain positive collaborative relationships with families and the larger community toning and support well-being. That students "is why teachers should be prepared with universal values, such as freedom, justice, human rights, gender equality, tolerance, and respect for the right to live.

In order to achieve the objectives of peace education, a school system has to be prepared for drastic changes including setting new educational objectives, preparing new curricula, (re)writing school textbooks, developing instructional material, and training teachers to create a school climate that is conducive to peace education. Researchers further argue that teacher education programs need to provide opportunities for collaborative and interactive learning so that teachers can make the peace values part of their own personality. Similarly, Brock-Utne, (1989) argue that the peace educator who works with students to develop a more positive and detailed concept of peace, plays a pivotal role in peace pedagogy. Mishra .L (2012) while developing their "Peace" ,Education on frame work the use of childcentered, innovative, and participative pedagogies. They emphasize combining pedagogy with curriculum content and creating a teacher resource that is easy to use and written in plain 
language. They argue in favor of working in line with the existing systems rather than attempting to bring about change by working against the prevailing systems. Similarly families and schools are the two most important institutions that influence concepts of hate and love. He argues that a cooperative learning environment, conflict management initiatives, the constructive use of controversy, and establishment of resolution dispute centers in schools will enhance a constructive relationship which will ultimately help prepare children to live in a peaceful world. Salomon (2002) suggests providing maximum opportunities of speaking and expressing their views to children which may in turn boost their moral courage and be part of their personality for their later life. It seems that one has to consider the strategies to be followed carefully when we want to foster peace education in schools. It is the responsibility of every teacher to introduce experience-based learning, group work, and discussion methods in classroom lessons. Teachers should not dominate the teaching-learning situation, but rather promote an open climate for discussion in which pupils feel free to participate. Pupils should learn to take up independent viewpoints and to make a contribution towards solving problems and resolving conflict situations. Teachers thus take the role of facilitator of learning, rather than the transmitter of knowledge.

Elaborating on the importance of schools for peace education, in the views of Harris, ve Morrison (2003), the pedagogy of peace education should be "a skills of listening, reflection, problem-solving, cooperation and conflict resolution. The process should aim at empowering people with the skills, attitudes, and knowledge that are instrumental in the creation of a safe and sustained world. More specifically, Bar-Tal (2002) argues that peace education stands to achieve the objectives which are dis- tinct from traditional educational objectives and therefore require a different pedagogy. $\mathrm{He}$ delineates the following implications for peace education pedagogy:

(1) Peace education is an orientation, more a philosophy than a subject matter;

(2) Peace education has to be open-minded to avoid becoming doctrinaire; has to embrace contrasting perspectives and alternate ways of seeing rather than reinforcing dogma;

(3) Peace education has to be relevant; it has to deal with the real problems lived by real people;

(4) Peace education requires experiential, active learning that increases internalization and reflection more than traditional didactic approaches can achieve;

(5) Peace education is teacher-dependent; without a teacher who understands and can model peace education, the enterprise will not succeed. The pivotal role played by the cultural and contextual realities and differences in peace education has been frequently highlighted in the contemporary research literature. In Kankardahard block of dehenkanal district of odisha mostly tribal students are enrolled to the school and drop out. Most tribal"s students are engaged in anti social activities a study intended to explore the perceptions of teachers and parents about peace education and the curriculum of peace education for secondary school.

\subsection{Objective of the study}

1) To study the perception of teachers and parents about the peace education in secondary schools of Odisha. 
2) To study about the component of peace education in secondary school curriculum of Board of secondary education Odisha.

3) To suggest measures for implementation of peace education in secondary schools of Odisha.

\subsection{Research Questions}

1) What will be the perception of teachers Parents about peace Education?

2) What component of peace Education will be included in the curriculum of secondary school of Odisha?

3) What are the measures for better implementation of the programme?

\section{METHODOLOGY}

\subsection{Research Design}

In order to obtain in-depth and descriptive data about the perception of teachers and parents about peace education within the natural setting of the secondary school of Odisha, India, a qualitative method was adopted for the study.

\subsection{Sampling}

Secondary schools of Kankadahard block of Dhenkanal district of Odisha, India were selected for the study. Out of these one government high school, one private High school, one Block grant high school and one Sevaasharam (residential school) school was selected randomly for the study.

\subsection{Participants}

This study was conducted in 4 secondary schools, the four head master and 3 teacher from each school i.e 12 (one science, one arts and one Physical Education teacher) was taken as the primary research participant during the july 2013 to may April 2014. In order to gain rich and in-depth data, 6 parents from each school i.e. a sum of 24 parents were selected for the study

\subsection{Data Gathering}

This study employed semi-structured interviews as the main tool of data collection. In order to ensure that the interviews comprehensively collected the perspectives of the principal participants, this study employed Focus Group Discussion with teachers and parents. The interview language was odiya and each interview was audio taped and personally transcribed by the researcher and later translated into English. The reliability of data was done by triangulation method

\section{ANALYSIS and FINDINGS}

With respect to the concept of peace education all the head masters were given their views that the inculcation and development of positive thinking and positive attitudes among the students in order to attain the ultimate goal of a better, more peaceful society for the future. While defining peace education, the head teachers maintained behaviour that for "Positive each other by the teachers and students help the school move forward. With a negative behaviour for each other by children and teachers, a school can never succeed".

Teachers of all the schools says that if children are taught from the very beginning about peace education it will have a positive impact on their future behavior and the role they play in bringing about positive changes in the society. 
Similar concept also given by the parents they says that peace education will develop the values among the students, they are very much serious about the degradation of culture and values among the students. So peace education will modify the behaviour and develop the Indian culture and tradition among the students. Healthy relationships, a friendly environment, the absence of fear, and feelings of safety were marked as the prominent features of peace education in the school said by the teachers.

Defining the concept of peace education the summery comes from the focus group discussion of the teachers that [peace education] means we should have good attitude and behaviour for each other. My behavior with my colleagues and students should be positive and work friendly. In other words, we can say that peace education means providing an environment to the students in which they feel safe and secure to learn.

Regarding to the content of peace education all most all the teacher says that Citizenship, duties, rights and obligations of citizens, functions and processes of government, voting and elections, leadership and followership. Learning about morality, norms and values, moral standards, rightness and wrongness of conducts and value systems such as tolerance, love, hard work, justice, respect for human life, and learning about the use of nonviolent alternatives to resolve conflicts e.g. dialogue, peaceful protests and rallies should be included in secondary school curriculum.

Answering to the research question two regarding the mode of transacting peace education in secondary school both curricular and co curricular activities mode was said by the teachers as well as parents. Parents were giving much more importance on curricular activities like organising seminars, debates, games. Peace march, peace club etc. Teachers are also give their perception on peace concept should included in classroom teaching and curriculum both formal and non formal way. You know as teachers we play the role of change agents and we can bring about positive change in the society through our students. We can help in bringing peace in the society by teaching peace education to our students. Children always tell their parents what they learn in the school, so in this way the message of peace can reach out to the society through children was opined by one teacher of Rxaibol High School in focus group discussion.

Table 1. Concept and Compnets of Peace Education

\begin{tabular}{|c|c|c|c|c|}
\hline Themes & $\begin{array}{l}\text { Concept of peace Educa- } \\
\text { tion }\end{array}$ & $\begin{array}{l}\text { Different Types } \\
\text { Of Peace } \\
\text { Education }\end{array}$ & $\begin{array}{l}\text { Components of peace } \\
\text { education }\end{array}$ & $\begin{array}{l}\text { Ways of transacting } \\
\text { peace education }\end{array}$ \\
\hline
\end{tabular}

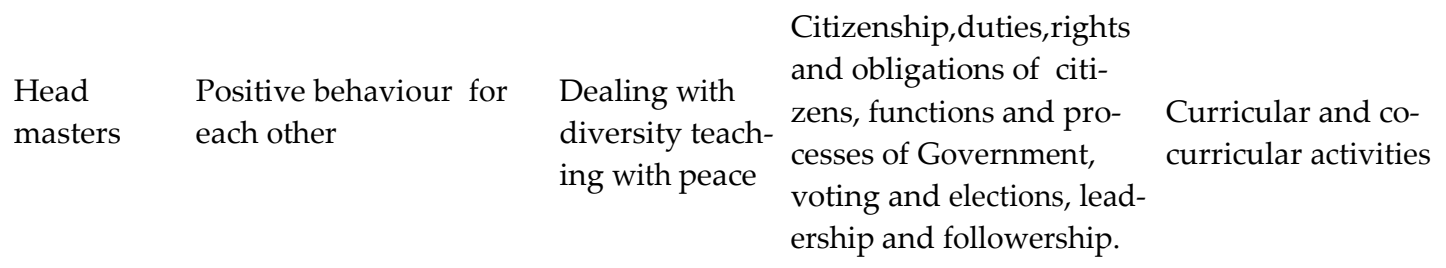




\begin{tabular}{|c|c|c|c|}
\hline Teachers & $\begin{array}{l}\text { Peace education means } \\
\text { living in peace, improving } \\
\text { our relationship and shar- } \\
\text { ing our learning each } \\
\text { other }\end{array}$ & $\begin{array}{l}\text { Helping stu- } \\
\text { dents for cop- } \\
\text { ration ,tolerance } \\
\text {,behaviour } \\
\text {,improving } \\
\text { peace compo- } \\
\text { nents life skill } \\
\text { education }\end{array}$ & $\begin{array}{l}\text { Learning about legal is- } \\
\text { sues, child rights and Curricular and co } \\
\text { freedoms and their obliga-curricular activities } \\
\text { tions, international human extra curricular } \\
\text { rights instruments in activities In-service } \\
\text { promoting, protecting and and Pre-service } \\
\text { defending human Rights. training programme } \\
\text { Political, economic and for teachers } \\
\text { social justice. }\end{array}$ \\
\hline
\end{tabular}

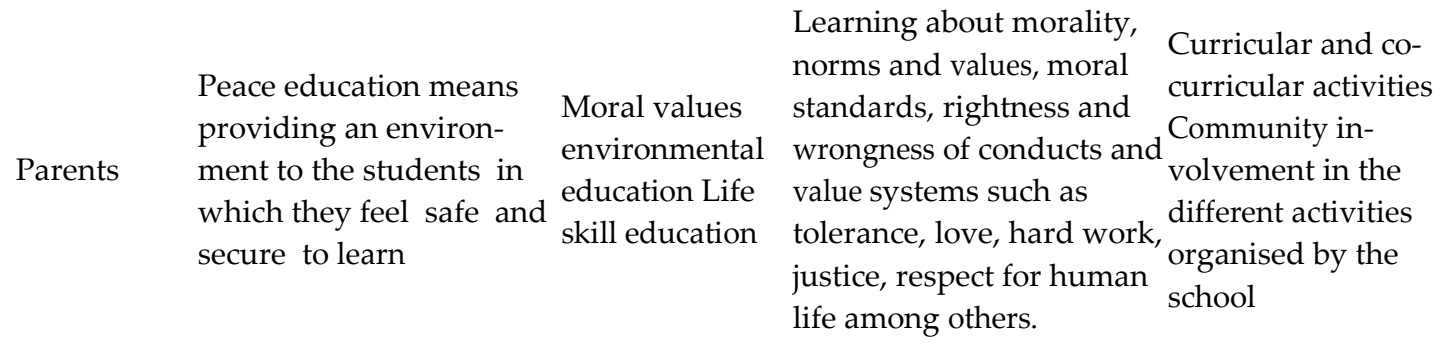

The table above articulates a comprehensive peace education curriculum for dealing with Violence and conflict in secondary schools in Odisha. Generally, the introduction of this Curriculum seeks to engineer positive attitudes, increase tolerance and acceptance of others, While seeking to eliminate prejudices and stereotypes, encouraged of" others" enhance positive an perception conflict resolution and problem solving skills among students, teachers and administrators in the secondary school system. in service and pre service teacher training programme may be organised by the government . community member will be more involved in the co curricular activities organised by the school for better implementation of the programme.

\section{CONCLUSION}

In the light of the study, it is suggested that the government education department odisha may revisit its educational strategy to incorporate and integrate a planned and organized component of peace education at the school level. The head teacher and teachers and parents were seemed to be unsatisfied with the societal culture and try their level best to avoid the communal culture and create their own environment in the school. Without taking the parent community in loop, the efforts of peace education may not give the desired results. Therefore it is suggested that particularly, the integration of peace education and parental involvement in the school may give fruitful results. Therefore, the local teacher education institution of the region may include the parental involvement in peace education in their training programs for the teachers. However, such a program will be beneficial and easy to install if it is integrated as part of the existing educational practices rather than aiming for drastic changes. 


\section{References}

Abu-Nimer, M. (2000). Peace building in postsettlement: Challenges for Israeli and Palestinian peace educators. Peace and Conflict: Journal of Peace Psychology, 6(1), 1-21.

Begum, A. (2012). The concept and perception of peace education in Gilgit Baltistan Pakistan: A comparative case study. The Peace and Conflict Review, 7(1), 25-39.

Bar-Tal, D. (2002). The elusive nature of peace education. Peace education: The concept, principles, and practices around the world, G. Salomon and B. Nevo (Eds). London, Lawrence Erlbaum, 27-36.

Bar-Tal, D. and Rosen, Y. (2009). Peace education in societies involved in intractable conflicts: Direct and indirect models. Review of Educational Research, 79(2), 557-575.

Baldo, M. and Fumiss, E. (1998). Integrating life skills into the primary curriculum. New York, UNICEF.

Brock-Utne., B. (1989). Feminist Perspectives on Peace and Peace Education (1st ed). New York: Pergamon Press.

Creswell, J. W. (2003). Research design: Qualitative, quantitative, mixed method approaches (2nd ed.). California: Sage publication.

McGregor, S. (2001). Leadership for the human family: Reflective human action for a culture of peace. Mount Saint Vincent University, NOVA Scotia.

Gumut, V. (2006). Peace education and peer mediation. Introduction to peace and conflict studies in West Africa: A reader. Ibadan: Spectrum Books Limited, 27-36.

Harris, I. M. and Morrison, M. L. (2003). Peace Education (2nd Ed.) Jefferson, NC: McFarland.

Momodu, A. J. (2013). Mainstreaming Peace Education in Secondary School Curricula in Nigeria. International Journal of English and Education, 2(2), 535-546.

Mishra, L. (2012). Peace education a frame work of teachers. APH publishers New Delhi

Mishra, L. (2013). Peace Education as a Tool for Effective Conflict Management in Secondary Schools. Sakarya University Journal of Education, 3(1), 69-76.

Oshita, O.O. (2006). Peace education in Nigeria: partnerships and prospects. Journal of the Society for Peace Studies and Practice, 1(1), .

Salomon, G. and Nevo, B. (2002). Peace education: the concept, principles, and practices around the world. New York, Lawrence Etlbaum. 